\title{
Pengaruh komunikasi internal terhadap motivasi belajar siswa
} (Effect of internal communication to student learning motivation)

\author{
Retno Puji Pratiwi', Tjutju Yuniarsih ${ }^{2 *}$
}

\author{
1,2Program Studi Pendidikan Manajemen Perkantoran, \\ Fakultas Pendidikan Ekonomi dan Bisnis, Universitas Pendidikan Indonesia \\ Jl. Dr. Setiabudhi, No. 229 Bandung, Jawa Barat Indonesia \\ Email: yuniarsih@upi.edu
}

\begin{abstract}
ABSTRAK
Penelitian ini bertujuan untuk menganalisis pengaruh komunikasi internal terhadap motivasi belajar. Metode penelitian menggunakan explanatory survey. Teknik pengumpulan data menggunakan angket (kuesioner) dengan model skala likert. Responden adalah siswa kelas XI SMK Kiansantang Bandung sebanyak 69 orang. Teknik analisis data menggunakan analisis regresi. Hasil penelitian menunjukkan: (1) komunikasi internal berapa pada kategori baik; (2) motivasi belajar di SMK Kiansantang Bandung berada pada kategori sedang; dan (3) komunikasi internal memiliki pengaruh positif dan signifikan terhadap motivasi belajar siswa.
\end{abstract}

Kata Kunci: komunikasi internal; motivasi belajar.

\begin{abstract}
This study aimed to analyze the implementation of internal communication toward student learning motivation. This research used explanatory survey method. Technique of collecting data using questionnaire with likert scale. Respondents are students of class XI SMK Kiansantang Bandung with the number of 69 people. Data analysis technique is by way of regression analysis. The result showed: (1) the internal communication is in good category; (2) the motivation to learn in SMK Kiansantang Bandung is in the medium category; and (3) internal communication has a positive and significant influence on student learning motivation.
\end{abstract}

Keywords: internal communication; learning motivation.

\section{PENDAHULUAN}

Effendi, Syaiful Bahri Djamarah, dan Aswan Zain (2006, hlm. 10) mengemukakan bahwa: "Belajar adalah proses perubahan perilaku berkat pengalaman dan latihan. Artinya, tujuan kegiatan belajar adalah perubahan perilaku, baik yang menyangkut pengetahuan, keterampilan maupun sikap, bahkan meliputi segenap aspek organisme atau pribadi." Belajar adalah kegiatan yang berproses dan merupakan unsur yang sangat fundamental dalam penyelenggaraan setiap jenis dan jenjang pendidikan. Ini berarti, bahwa berhasil atau gagalnya pencapaian tujuan pendidikan itu amat bergantung pada proses belajar yang dialami siswa, baik ketika ia berada di sekolah

Received: Agustus 2018, Revision: November 2018, Published: Januari 2019 
maupun di lingkungan rumah atau keluarganya sendiri. (Muhibbin Syah, 2009, hlm. 63). Menurut Asri Budiningsih (2005, hlm. 21) belajar merupakan proses interaksi antara stimulus dan respon. Untuk menghasilkan suatu perubahan yang baik atau hasil dari belajar yang positif, ada beberapa faktor yang dapat mempengaruhinya, salah satunya adalah motivasi yang tinggi. Pada aktivitas belajar mengajar, setiap siswa membutuhkan motivasi atau dorongan agar keinginannya dapat terpenuhi. Motivasi tersebut bisa didapatkan dari dua faktor yang mempengaruhi pelaksanaan belajar mengajar, yaitu faktor internal dan faktor eksternal. Slameto (2010, hlm 66), menyebutkan bahwa "Salah satu faktor eksternal dari lingkungan sekolah yang mempengaruhi motivasi belajar peserta didik adalah relasi guru dengan siswa."

Wibowo dan Hamrin (2012, hlm 2014) menyatakan bahwa guru harus memiliki interpersonal skill yang meliputi keterampilan berkomunikasi, keterampilan memberikan motivasi, keterampilan bekerjasama membangun tim, dan keterampilan menjadi mediator dan negosiator. Jadi, dapat disimpulkan bahwa komunikasi internal merupakan salah satu faktor yang memberikan pengaruh terhadap motivasi belajar siswa.

Fokus masalah dalam penelitian ini adalah rendahnya motivasi belajar siswa. Menurut Sardiman A. M (2011, hlm. 75) motivasi belajar adalah "Keseluruhan daya penggerak di dalam diri siswa yang menimbulkan kegiatan belajar, yang menjamin kelangsungan dari kegiatan belajar dan yang memberikan arahan pada kegiatan belajar, sehingga tujuan yang dikehendaki oleh subjek belajar itu dapat tercapai." Berkaitan dengan upaya meningkatkan motivasi belajar, maka diperlukan komunikasi yang baik antara guru dengan siswa, maupun siswa dengan siswa. Komunikasi yang efektif perlu dilakukan dalam sebuah organisasi agar tercapainya suasana terbuka, nyaman dan kondusif sehingga tujuan organisasi dapat tercapai. Berdasarkan hal tersebut rumusan masalah pada penelitian ini adalah "adakah pengaruh komunikasi internal terhadap motivasi belajar?" Dengan demikian tujuan penelitian ini adalah untuk menganalisis pengaruh komunikasi internal terhadap motivasi belajar.

\section{TINJAUAN PUSTAKA \\ Komunikasi Internal}

Davis dalam Mangkunegara (2008, hlm. 145) mengemukakan "comunication is the transfer of information and understanding from one person to another person". (Komunikasi merupakan sebuah transfer atau pemindahan informasi dan pemahaman dari seseorang yaitu komunikator kepada orang lain atau disebut dengan komunikan). Stephen P. Robbins \& Timothy A. Judge (2015, hlm. 224), "Komunikasi membantu meningkatkan motivasi dengan menjelaskan kepada para pekerja mengenai apa yang harus mereka lakukan, seberapa baik mereka dalam melakukannya, dan bagaimana mereka dapat meningkatkan kinerja mereka. Pembentukan tujuan, memberikan umpan balik atas kemajuan, dan memberikan imbalan bagi perilaku yang diinginkan semuanya mendorong motivasi dan memerlukan komunikasi."

Stephen P. Robbins \& Timothy A. Judge (2015, hlm. 223) menyebutkan bahwa, Komunikasi melakukan empat fungsi organisasi: pengendalian, motivasi, pernyataan emosional, dan informasi.

Arni Muhammad (2009, hlm. 97) mendefinisikan "Komunikasi internal adalah komunikasi yang dikirimkan kepada anggota dalam suatu organisasi, dengan kata lain penerima pesan adalah orang dalam organisasi." Sedangkan menurut Brennan (dalam 
Effendy 2009, hlm. 122) "komunikasi internal adalah pertukaran gagasan di antara para administrator dan pegawai dalam suatu organisasi atau instansi yang menyebabkan terwujudnya organisasi tersebut lengkap dengan strukuturya yang khas dan pertukaran gagasan secara horizontal dan vertikal dalam suatu organisasi yang menyebabkan pekerjaan berlangsung (operasi manajemen)". Dapat disimpulkan, komunikasi internal merupakan komunikasi yang terjadi di antara seseorang dalam suatu organisasi atau kelompok yang memiliki hubungan yang cukup dekat.

Menurut Effendy, dkk. (2009, hlm. 122) "komunikasi internal ditunjang oleh dua jalur komunikasi, yaitu komunikasi vertikal dan komunikasi horizontal". Umar (2010, hlm. 26) menyebutkan indikator dari komunikasi internal antara lain: (1) Keterbukaan, (2) Empati, (3) Dukungan, (4) Kepositifan, dan (5) Kesamaan.

\section{Motivasi Belajar}

Nana Syaodih Sukmadinata (2005, hlm. 61) mengemukakan bahwa, "Kekuatan yang menjadi pendorong kegiatan individu disebut motivasi, yang menunjukkan suatu kondisi dalam diri individu yang mendorong atau menggerakkan individu tersebut melakukan kegiatan mencapai suatu tujuan." Sardiman A. M (2011, hlm. 75) motivasi belajar adalah "Keseluruhan daya penggerak di dalam diri siswa yang menimbulkan kegiatan belajar, yang menjamin kelangsungan dari kegiatan belajar dan yang memberikan arahan pada kegiatan belajar, sehingga tujuan yang dikehendaki oleh subjek belajar itu dapat tercapai." Dalam kegiatan belajar, maka motivasi dapat dikatakan sebagai keseluruhan daya penggerak dalam diri siswa yang menimbulkan kegiatan belajar, yang menjamin kelangsungan dari kegiatan belajar dan yang memberi arah pada kegiatan belajar, sehingga tujuan yang dikehendaki oleh subjek belajar yang tercapai.

Menurut Sardiman (2011, hlm. 86), motivasi dapat dilihat dari dasar pembentukannya, yaitu: (1) Motif-motif bawaan adalah motif yang dibawa sejak lahir, jadi motivasi itu ada tanpa dipelajari, misalnya dorongan untuk makan, dorongan untuk minum, dorongan untuk bekerja, untuk beristirahat, doroangan seksual, dan lain-lain. (2) Motif-motif yang dipelajari adalah motif-motif yang timbul karena dipelajari, contohnya dorongan untuk belajar suatu cabang ilmu pengetahuan, dorongan untuk mengajar sesuatu dalam masyarakat.

Effendi dan Syaiful Bhari Djamarah (2008, hlm. 123-124) menyebutkan tiga fungsi motivasi dalam belajar, yaitu: (1) Motivasi sebagai pendorong perbuatan, (2) Motivasi sebagai penggerak kegiatan, dan (3) Motivasi sebagai pengarah perbuatan.

Suryabrata (2004), beberapa faktor yang mempengaruhi motivasi belajar, yaitu:

1) Faktor Eksternal, yaitu faktor dari luar individu yang terbagi menjadi dua: faktor sosial meliputi faktor manusia lain baik hadir secara langsung atau tidak langsung, dan faktor non sosial meliputi keadaan udara, suhu udara, cuaca, waktu, tempat belajar, dan lain-lain.

2) Faktor Internal, yaitu faktor dari dalam diri individu yang terbagi menjadi dua: faktor fisiologis meliputi keadaan jasmani, dan keadaan fungsi-fungsi fisiologis dan faktor psikologis meliputi minat, kecerdasan, dan persepsi.

Indikator untuk mengukur motivasi dalam penelitian ini merujuk pada pendapat Wena (2010, hlm 33), yaitu: (1) Keantusiasan dalam belajar; (2) Minat atau perhatian pada pembelajaran; (3) Keterlibatan dalam kegiatan belajar; (4) Rasa ingin tahu pada isi 
pembelajaran; (5) Ketekunan dalam belajar; (6) Selalu berusaha mencoba; dan (7) Aktif mengatasi tantangan yang ada dalam pembelajaran.

\section{METODE PENELITIAN}

Suharsimi Arikunto (2006, hlm. 160) mengungkapkan bahwa "Metode penelitian adalah cara yang digunakan oleh peneliti dalam mengumpulkan data." Berdasarkan variabel yang diteliti, maka jenis penelitian ini merupakan penelitian deskriptif dan verifikatif. Berdasarkann jenis penelitiannya yaitu deskripstif dan verifikatif yang dilakukan melalui pengumpulan data di lapangan, maka metode penelitian yang digunakan adalah metode explanatory survey. Metode ini dianggap tepat karena penelitian ini dilakukan untuk mengumpulkan informasi faktual melalui penggunaan kuesioner untuk menguji hipotesis. Responden diambil dari seluruh siswa kelas XI di SMK Kiansantang Bandung sebanyak 69 orang.

Instrumen pengumpulan data berupa angket model rating scale yang terdiri atas dua bagian. Bagian pertama terdiri atas 13 item, adalah kuesioner untuk mengukur persepsi responden terhadap komunikasi internal yang dijabarkan dari lima indikator yaitu keterbukaan, empati, dukungan, kepositifan, dan kesamaan. Bagian kedua terdiri dari 14 item adalah kuesioner untuk mengukur persepsi responden terhadap motivasi belajar yang dijabarkan dari tujuh indikator yaitu keantusiasan dalam belajar, minat atau perhatian pada pembelajaran, keterlibatan dalam kegiatan belajar, rasa ingin tahu pada isi pembelajaran, ketekunan dalam belajar, selalu berusaha mencoba, dan aktif mengatasi tantangan yang ada dalam pembelajaran.

Statistik deskriptif menggunakan skor rata-rata yang digunakan untuk memperoleh gambaran tingkat persepsi responden mengenai komunikasi internal dan motivasi belajar. Statistik inferensial menggunakan analisis regresi yang digunakan untuk menguji hipotesis.

\section{HASIL PENELITIAN DAN PEMBAHASAN \\ Komunikasi Internal}

Komunikasi internal menurut persepsi responden berada dalam kategori cukup baik. Hal ini ditandai dengan perolehan hasil rata-rata sebesar 3,27. Tabel 1 menyajikan skor rata-rata dari masing-masing indikator yang dijadikan ukuran komunikasi internal.

Tabel 1.

Komunikasi Internal

\begin{tabular}{|l|c|c|}
\hline \multicolumn{1}{|c|}{ Indikator } & Rata-rata & Penafsiran \\
\hline Keterbukaan & 3,21 & Cukup baik \\
\hline Empati & 3,37 & Cukup baik \\
\hline Dukungan & 3,14 & Cukup baik \\
\hline Kepositifan & 3,27 & Cukup baik \\
\hline Kesamaan Rata-rata & 3,41 & Baik \\
\hline \multicolumn{1}{|c|}{} & 3,27 & Cukup baik \\
\hline
\end{tabular}

Skor tertinggi berada pada indikator daya tanggap yaitu sebesar 3,41. Hasil ini menunjukkan bahwa komunikasi antarpribadi akan lebih efektif jika terjadi dalam suasana kesamaan sehingga muncul rasa saling hormat dan saling menghargai. 
Indikator dengan skor rata-rata terendah yaitu sebesar 3,21. Hasil ini mengandung makna bahwa pengungkapan reaksi atau tanggapan terhadap situasi yang sedang dihadapi masih kurang.

\section{Motivasi Belajar}

Motivasi belajar menurut persepsi responden berada dalam kategori sedang. Hal ini ditandai dengan perolehan hasil rata-rata sebesar 3,01. Tabel 2 menyajikan skor ratarata dari masing-masing indikator yang dijadikan ukuran motivasi belajar.

Tabel 2.

Motivasi Belajar

\begin{tabular}{|l|c|c|}
\hline \multicolumn{1}{|c|}{ Indikator } & Rata-rata & Penafsiran \\
\hline Antusias & 3,22 & Sedang \\
\hline Minat dalam pembelajaran & 2,92 & Sedang \\
\hline Keterlibatan dalam kegiatan di kelas & 3,36 & Sedang \\
\hline Rasa ingin tahu pada isi pembelajaran & 2,90 & Sedang \\
\hline Ketekunan dalam belajar & 2,90 & Sedang \\
\hline Selalu berusaha mencoba & 3,12 & Sedang \\
\hline $\begin{array}{l}\text { Aktif dalam mengatasi tantangan yang ada dalam } \\
\text { pembelajaran }\end{array}$ & 2,69 & Sedang \\
\hline \multicolumn{1}{|c|}{ Rata-rata } & 3,01 & Sedang \\
\hline
\end{tabular}

Skor tertinggi berada pada indikator keterlibatan dalam kegiatan di kelas yaitu sebesar 3,36. Hal ini menunjukan bahwa siswa memiliki tingkat keterlibatan untuk aktif di kelas dalam kegiatan belajar sudah cukup baik.

Indikator rasa ingin tahu pada isi pembelajaran dan indikator ketekunan dalam belajar memiliki skor rata-rata terendah yaitu sebesar 2,90. Hal tersebut menunjukan bahwa kedua indikator tersebut masih berada pada kategori sedang sehingga perlu adanya upaya meningkatkan hal tersebut.

\section{Pengaruh Komunikasi Internal terhadap Motivasi Belajar}

Persamaan regresi yang menunjukkan komunikasi internal terhadap motivasi belajar adalah $\hat{Y}=23,597+0,451 x$. Tanda positif $(+)$ menunjukkan hubungan antara variabel berjalan satu arah artinya semakin efektif komunikasi internal, maka semakin tinggi tingkat motivasi belajar. Nilai koefisien determinasi $\left(\mathrm{R}^{2}\right)$ variabel komunikasi internal terhadap motivasi belajar adalah sebesar 16\%. Sehingga dapat ditarik kesimpulan bahwa determinasi variabel komunikasi internal mampu mempengaruhi variabel motivasi belajar sebesar $16 \%$. Angka tersebut mengisyaratkan bahwa variabel motivasi belajar dipengaruhi oleh faktor lain sebesar $84 \%$.

Hasil ini sejalan dengan penelitian yang menyimpulkan bahwa penerapan komunikasi internal memberikan pengaruh terhadap kepuasan pelanggan motivasi belajar (Yuanita). Hal ini juga sejalan dengan beberapa pendapat ahli yang menyatakan bahwa Stephen P. Robbins (2015, hlm. 224) menyebutkan bahwa, "Komunikasi membantu meningkatkan motivasi". Selain itu Stephen P. Robbins \& Timothy A. Judge (2015, hlm. 223) menyebutkan bahwa, komunikasi melakukan empat fungsi organisasi: pengendalian, motivasi, pernyataan emosional, dan informasi. Sentot Imam Wahyono (2010, hlm. 218) salah satu fungsi komunikasi adalah motivasi, yaitu dengan 
komunikasi dapat menjelaskan pada para anggota apa yang harus dikerjakan dan bagaimana dapat bekerja dengan baik.

\section{KESIMPULAN}

Komunikasi internal yang meliputi keterbukaan, empati, dukungan, kepositifan, dan dukungan berada pada kategori cukup baik. Motivasi belajar yang diukur melalui indikator keantusiasan dalam belajar, minat atau perhatian pada pembelajaran, keterlibatan dalam kegiatan belajar, rasa ingin tahu pada isi pembelajaran, ketekunan dalam belajar, selalu berusaha mencoba, dan aktif mengatasi tantangan yang ada dalam pembelajaran berapa pada kategori sedang.

Komunikasi internal berpengaruh positif dan signifikan terhadap motivasi belajar. Dengan demikian peningkatan komunikasi internal akan diikuti oleh peningkatan motivasi belajar. Implikasi dari hasil penelitian ini untuk pihak sekolah dalam meningkatkan motivasi belajar yaitu meningkatkan efektivitas komunikasi internal

\section{DAFTAR PUSTAKA}

Arikunto, Suharsimi. (2006). Prosedur Penelitian, Suaru Pendeketan Praktek. Jakarta: Rineka Cipta.

Budiningsih, Asri. (2005). Belajar dan Pembelajaran. Semarang: PT. Rineka Press.

Effendy, Djamarah, Syaiful Bahri \& Aswan Zain. (2009). Strategi Belajar Mengajar. Jakarta: Rineka Cipta

Mangkunegara. (2008). Manajemen Sumber Daya Manusia Perusahaan. Bandung: Remaja Rosdakarya.

Muhammad, Arni. (2009). Komunikasi Organisasi. Jakarta: Bumi Aksara

Robbins, Stephen P. \& Timothy A. Judge. (2015). Perilaku Organisasi Edisi 16. Jakarta: Salemba Empat.

Sardiman, A.M. (2011). Interaksi dan Motivasi Belajar Mengajar. Jakarta: Perawi Pers. Slameto. (2010). Belajar dan Faktor-faktor yang Mempengaruhinya. Jakarta: PT Rineka Cipta.

Suryabrata, Sumadi. (2004). Psikologi Pendidikan. Jakarta: PT Raja Grafindo Persada

Syaodih, S. Nana \& R Ibrahim. (2005). Perencanaan Pengajaran. Jakarta: Rineka Cipta Syah, Muhibbin. (2009). Psikologi Belajar. Jakarta: PT Raja Grafindo Persada.

Umar, Husein. 2010. Desain Penelitian MSDM dan Perilaku Karyawan. Bandung: Rajawali Universitas Surabaya

Yuanita Widyanti Sofiana Sari. Pengaruh Komunikasi Internal, Reward dan Punisment Terhadap Motivasi Kerja Karyawan di BPR Nur Semesta Indah Kencong Kabupaten Jember. Jember: Tidak diterbitkan

Wahjono, Sentot I. (2010). Perilaku Organisasi. Yogyakarta: Graha Ilmu.

Wena, Made. (2010). Strategi Pembelajaran Inovatif Kontemporer. Jakarta: Bumi Aksara

Wibowo \& Hamrin. (2012). Komunikasi Interpersonal dalam Komuniasi Pembelajaran. Jakarta: Salemba Empat 